\title{
Pengaruh Kualitas Pelayanan dan Corporate Social Responsibility terhadap Citra Perusahaan
}

\author{
Risna Nurjanah ${ }^{1}$, Ade Sofyan Mulazid ${ }^{2}$ \\ ${ }^{1,2}$ Fakultas Ekonomi dan Bisnis, UIN Syarif Hidayatullah Jakarta, Indonesia \\ risnanurjannah97@gmail.com ${ }^{1}$; adesofyanmulazid@uinjkt.ac.id ${ }^{2}$
}

Masuk: 25 Februari 2018; Diterima: 6 Juni 2018; Terbit: 25 Juni 2018

\begin{abstract}
This research aims to analyze the quality of service and corporate social responsibility of BNI Syariah against corporate image in PT BNI Syariah Center, Jakarta. Sampling technique used in this research is convenience sampling method, and then the data was analyzed by using multiple linear regression analysis method. Sample in this research is BNI Syariah Center customer, Jakarta amounted to 100 respondents. This research is a quantitative research and data analysis method is using multiple liniear regression. The result of this research shows that partially service quality and corporate social responsibility variables significantly influence the image of the company in syariah bank. Simultaneously the service quality and corporate social responsibility variables significantly influence the image of the company in syariah bank at the level of significance less than 0.05 or $5 \%$.
\end{abstract}

Keywords: Service Quality, Corporate Social Responsibility, Image Company.

\begin{abstract}
Abstrak
Penelitian ini bertujuan untuk menganalisis kualitas pelayanan dan corporate social responsibility BNI Syariah terhadap citra perusahaan di PT BNI Syariah Pusat, Jakarta. Teknik pengambilan sampel yang digunakan dalam penelitian ini adalah metode convenience sampling. Kemudian data diproses dengan menggunakan metode analisis regresi linear berganda. Sampel dalam penelitian ini merupakan nasabah BNI Syariah Pusat, Jakarta berjumlah 100 responden. Penelitian ini adalah penelitian kuantitatif dan metode analisis data menggunakan regresi liniear berganda. Hasil dari penelitian ini menunjukan bahwa secara parsial variabel kualitas pelayanan dan corporate social responsibility berpengaruh secara signifikan terhadap citra perusahaan di bank syariah. Secara simultan variabel kualitas pelayanan dan corporate social responsibility berpengaruh secara signifikan terhadap citra perusahaan di bank syariah pada tingkat signifikansi kurang dari 0,05 atau $5 \%$.
\end{abstract}

Kata Kunci: Kualitas Pelayanan, Corporate Social Responsibility, Citra Perusahaan. 


\section{PENDAHULUAN}

Kesuksesan yang diraih oleh perbankan syariah saat ini merupakan hasil jerih payah bank syariah sejak tahun 1992 yang terus berupaya mengembangkan diri dari tahun ke tahun. Pada tanggal 29 April tahun 2000, hadir Unit Usaha Syariah (UUS) Bank Negara Indonesia Syariah (BNI Syariah) yang turut memberikan sumbangsih atas berkembangnya bank syariah di Indonesia. Hingga akhirnya pada tanggal 19 Juni 2010, BNI Syariah berubah status dari Unit Usaha Syariah (UUS) menjadi Bank Umum Syariah (BUS) yang hadir mempersembahkan sebuah bank ritel modern terkemuka dengan layanan finansial sesuai kebutuhan nasabah. Melayani para nasabah dengan pelayanan prima (service excellent) dan menawarkan beragam produk yang sesuai harapan nasabah dengan prinsip syariah.

Melayani nasabah dengan pelayanan yang prima tentu sangat sulit. Hal tersebut dikarenakan dalam setiap pelayanannya, bank tidak bisa secara keseluruhan melakukan pelayanan tanpa kesalahan. Banyak sekali faktor-faktornya sehingga menimbulkan kesalahan yang mempengaruhi dalam melayani para nasabah, seperti kesalahan dari sumber daya manusia, kesalahan produk, maupun kesalahan-kesalahan yang bersifat non-teknis lainnya.

Persepsi nasabah atas nilai dan kualitas seringkali ditentukan oleh pelayanan para nasabah yang mengiringi produk utama perusahaan. Nasabah membutuhkan informasi yang lengkap dan jelas, layanan yang lebih cepat serta kenyamanan dalam pelayanan di samping produk utama yang mereka inginkan. Ada beberapa faktor yang menyebabkan nasabah mengeluh terhadap pelayanan yang dilakukan oleh BNI Syariah sebagaimana ditampilkan pada Tabel 1.

Tabel 1. Fenomena Keluhan terhadap Kualitas Pelayanan BNI Syariah

\begin{tabular}{clcc}
\hline No & \multicolumn{1}{c}{ Keterangan } & Frekuensi & Persentase \\
\hline 1. & Pelayanan customer service yang lambat & 15 & $15 \%$ \\
2. & $\begin{array}{l}\text { Antrian nasabah yang kurang cepat berjalan akibat } \\
\text { kurangnya jumlah teller }\end{array}$ & 45 & $45 \%$ \\
3. & $\begin{array}{l}\text { Fasilitas kantor untuk pelanggan yang minim } \\
\text { 4. }\end{array}$ & 10 & $10 \%$ \\
& $\begin{array}{l}\text { Penjelasan yang kurang pada produk yang ditawar- } \\
\text { 5. }\end{array}$ & 5 & $5 \%$ \\
Permasalahan transfer antar bank yang terkadang & 5 & $5 \%$ \\
6. & Fasilitas belum cepat & 20 & $20 \%$ \\
\hline & Total & 100 & $100 \%$ \\
\hline
\end{tabular}

Sumber: www.bnisyariah.co.id

Kualitas layanan memberikan dorongan kepada pelanggan untuk menjalin hubungan yang erat dengan perusahaan, sehingga memungkinkan perusahaan untuk memahami dengan seksama harapan dan kebutuhan, yang pada akhirnya kepuasan pelanggan dapat menciptakan kesetiaan atau loyal kepada perusahaan. Dalam jangka panjang, loyalitas pelanggan menjadi tujuan bagi perencanaan pasar strategik 
(Kotler, 1997). Selain itu, dapat dijadikan dasar untuk pengembangan kompetitif yang berkelanjutan, yaitu keunggulan yang dapat direalisasikan melalui upaya-upaya pemasaran (Dick \& Basu, 1994).

Keyakinan atau kepercayaan adalah faktor penting yang dapat mengatasi krisis dan kesulitan antara rekan bisnis, selain itu juga merupakan aset penting dalam mengembangkan hubungan jangka panjang antar organisasi. Suatu organisasi harus mampu mengenali faktor-faktor yang dapat membentuk kepercayaan tersebut agar dapat menciptakan, mengatur, memelihara, menyokong dan mempertinggi tingkat hubungan dengan pelanggan (Karsono, 2008). Doney dan Cannon (1997) menyatakan bahwa kepercayaan merupakan suatu proses menghitung (calculative process) antara biaya yang dikeluarkan dengan hasil yang diperoleh. Pelayanan baik yang diterima sekarang akan berlanjut untuk ke depannya, sehingga kualitas pelayanan berpengaruh positif terhadap citra sebuah perusahaan.

Sebagai korporasi yang bertanggungjawab, BNI Syariah juga berkomitmen untuk mengedepankan kinerja dan pencapaian yang tidak hanya diukur melalui profit semata. Oleh karena itu, implementasi program corporate social responsibility menjadi bentuk perwujudan investasi sosial dari BNI Syariah kepada masyarakat. Melalui implementasi program corporate social responsibility yang berkelanjutan dan terarah, BNI Syariah berharap agar masyarakat dapat merasakan manfaat dari kehadiran perusahaan melalui upaya peningkatan taraf hidup dan kesejahteraan masyarakat secara keseluruhan.

Tabel 2. Fenomena Corporate Social Responsibility

\begin{tabular}{clcc}
\hline No & \multicolumn{1}{c}{ Keterangan } & Frekuensi & Persentase \\
\hline 1. & $\begin{array}{l}\text { Mengetahui corporate social responsibility } \\
\text { Bank BNI Syariah }\end{array}$ & 6 & $20 \%$ \\
2. & $\begin{array}{l}\text { Mengetahui Program corporate social responsi- } \\
\text { bility BNI Syariah }\end{array}$ & 6 & $20 \%$ \\
3. & $\begin{array}{l}\text { Menjadi salah satu penyumbang dana corporate } \\
\text { social responsibility BNI Syariah }\end{array}$ & 3 & $10 \%$ \\
\hline \multicolumn{1}{c}{ Total } & 30 & $100 \%$ \\
\hline
\end{tabular}

Sumber: www.bnisyariah.co.id

Dalam rangka mewujudkan salah satu misi perusahaan yang terkait dengan usaha menciptakan suatu kondisi yang ramah lingkungan terhadap masyarakat sekitarnya, BNI Syariah secara berkelanjutan dan sistematis menerapkan program corporate social responsibility. Melalui program ini, perusahaan berharap masyarakat akan merasakan manfaat dengan kehadiran BNI Syariah di lingkungan mereka dalam meningkatkan taraf hidup dan kesejahteraan. Fenomena corporate social responsibility pada lingkungan BNI syariah tercermin pada Tabel 2.

\section{Kualitas Layanan}

Menurut Kotler dan Keller (2012), kualitas adalah keseluruhan ciri serta sifat dari suatu produk atau pelayanan yang berpengaruh pada kemampuannya untuk memuaskan kebutuhan yang dinyatakan atau tersirat. Tjiptono (2010) menambahkan bahwa kualitas pelayanan adalah tingkat keunggulan yang diharapkan dan pengendalian atas tingkat 
keunggulan tersebut untuk memenuhi keinginan pelanggan. Dalam meningkatkan kualitas layanan, tentunya perusahaan harus meningkatkan citra perusahaan itu sendiri. Citra didefinisikan sebagai kesan atau suatu gambaran dari sebuah perusahaan di mata para khalayaknya yang terbentuk berdasarkan pengetahuan serta pengalaman mereka sendiri (Adona, 2006). Citra dengan sengaja perlu diciptakan agar bernilai positif. Hal positif yang dapat meningkatkan citra perusahaan melalui keberhasilan perusahaan. Dengan demikian, citra suatu perusahaan merupakan representasi dari suatu lembaga dengan harapan mampu mendorong citra perusahaan ke arah yang lebih baik.

Kualitas pelayanan akan memberikan kesempurnaan pelayanan untuk tercapainya keinginan atau harapan pelanggan. Zeithaml, Parasuraman, dan Berry (1985) menyatakan bahwa terdapat lima dimensi pokok dalam kualitas pelayanan, antara lain (1) keadaan (realibility), berkaitan dengan kemampuan perusahaan memberikan layanan yang disajikan secara akurat dan memuaskan; (2) daya tanggap (responsiveness), berkaitan dengan kesediaan dan kemampuan penyedia layanan untuk membantu para pelanggan dalam merespon permintaan mereka dengan segera; (3) jaminan (assurance), berkaitan dengan pengetahuan dan kesopanan karyawan serta kemampuan mereka dalam menumbuhkan rasa percaya dan keyakinan pelanggan; (4) empati (empathy), berkaitan dengan perusahaan memahami masalah para pelanggannya dan bertindak demi kepentingan pelanggan, serta memberikan perhatian personal dan pemahaman atas kebutuhan individual para pelanggan tersebut; dan (5) bukti fisik (tangibles), berkaitan dengan penampilan fisik fasilitas layanan, peralatan atau perlengkapan, sumber daya manusia dan materi komunikasi perusahaan.

Keterkaitan kualitas pelayanan dan citra perusahaan dalam penelitian ini didasari pada bahwa kualitas pelayanan berpengaruh positif terhadap citra perusahaan (Jasfar, 2009). Kualitas pelayanan menjadi salah satu hal yang penting terhadap citra perusahaan, baik buruknya suatu citra perusahaan tergantung pada bagaimana kualitas pelayanannya. Sehingga citra dapat memberikan persepsi publik tentang perusahaan menyangkut pelayanannya, kualitas produk, budaya perusahaan, perilaku perusahaan, atau perilaku individu-individu dalam perusahaan dan lainnya. Kualitas pelayanan publik menjadi suatu hal yang penting yang dapat mempengaruhi citra perusahaan karena pelayanan kepada publik ini dapat mempengaruhi persepsi individu mengenai perusahaan tersebut.

\section{Corporate Social Responsibility}

Corporate social responsibility merupakan komitmen perusahaan untuk membangun kualitas kehidupan yang lebih baik bersama dengan para pihak yang terkait, utamanya masyarakat di sekelilingnya dan lingkungan sosial dimana perusahaan berada (Mardikanto, 2014). Corporate social responsibility pada prinsipnya kegiatan yang memperhatikan keinginan dari semua stakeholder untuk keberlangsungan perusahaan itu sendiri. Elkington (1998) mengembangkan konsep triple bottom line dalam istilah economic prosperity, environmental quality dan social justice yang memberikan pandangan bahwa perusahaan yang ingin berkelanjutan harus memperhatikan 3P. Selain mengejar keuntungan (profit), perusahaan juga mesti memperhatikan dan terlibat pada pemenuhan kesejahteraan masyarakat (people) dan turut berkontribusi aktif dalam menjaga kelestarian lingkungan (planet).

Saat ini, perusahaan tidak lagi dihadapkan pada tanggungjawab yang berpijak pada single bottom line, yaitu aspek ekonomi yang direfleksikan dalam kondisi keuangan saja. 
Namun, harus memperhatikan aspek sosial, ekonomi dan lingkungan (Mardikanto 2014). Masyarakat sekarang lebih pintar dalam memilih produk yang akan mereka konsumsi. Sekarang, masyarakat cenderung untuk memilih produk yang diproduksi oleh perusahaan yang peduli terhadap lingkungan dan melaksanakan corporate social responsibility. Survei yang dilakukan Monitor (2001) menunjukkan bahwa mayoritas konsumen akan meninggalkan suatu produk yang mempunyai citra buruk atau diberitakan negatif. Sehingga saat ini perusahaan menggencarkan kegiatan corporate social responsibility guna menghilangkan citra buruk perusahaan karena tidak memperhatikan aspek sosial, ekonomi dan lingkungan.

Banyak manfaat yang diperoleh perusahaan dengan pelaksanan corporate social responsibility, antara lain produk semakin disukai oleh konsumen dan perusahaan diminati investor. Corporate social responsibility dapat digunakan sebagai alat pemasaran yang baru bagi perusahaan jika dapat dilaksanakan secara berkelanjutan. Untuk melaksanakan corporate social responsibility berarti perusahaan akan mengeluarkan sejumlah biaya. Biaya pada akhirnya akan menjadi beban yang mengurangi pendapatan sehingga tingkat profit perusahaan akan menurun. Padahal, jika dicermati lebih dalam dengan melaksanakan corporate social responsibility, citra perusahaan akan semakin meningkat sehingga berdampak pada loyalitas konsumen yang semakin meningkat.

Hubungan yang ideal antara profit, people dan planet harus seimbang, tidak bisa mementingkan satu elemen saja. Konsep 3P ini dapat menjamin keberlangsungan bisnis perusahaan. Hal ini dapat dibenarkan, sebab jika suatu perusahaan hanya mengejar keuntungan semata, bisa jadi lingkungan yang rusak dan masyarakat yang terabaikan menjadi hambatan kelangsungan bisnisnya. Beberapa perusahaan bahkan menjadi terganggu aktivitasnya karena tidak mampu menjaga keseimbangan 3P ini. Jika muncul gangguan dari masyarakat, maka akan merugikan bisnis itu sendiri (Prastowo \& Huda, 2011).

Hubungan antar corporate social responsibility dengan citra perusahaan terdapat pada pelaksanaan kegiatan corporate social responsibility yang dilakukan secara optimal sehingga target dari program corporate social responsibility tersebut dapat tercapai. Pelaksanaan yang membawa keuntungan bagi masyarakat atau targetnya, akan mendapat respon positif dari masyarakat. Jika suatu perusahaan memiliki citra yang positif, iklim penerimaan terhadap kinerja perusahaan oleh masyarakat akan menjadi semakin baik (Fitriani, 2012). Peningkatan tanggungjawab sosial terhadap komunitas lokal, menjadi acuan korporat dalam berlomba agar tetap eksis dan dapat berkompetisi dengan yang lainnya (Budimanta, Prasetijo, \& Rudito, 2004). Fakta telah menunjukan bagaimana resistensi masyarakat sekitar muncul ke permukaan terhadap perusahaan yang dianggap tidak memperhatikan faktor sosial dan lingkungan (Wibisono, 2007). Hal ini dikarenakan masyarakat telah semakin kritis dan mampu melakukan kontrol sosial terhadap dunia usaha.

Tuntutan terhadap perusahaan untuk memberikan informasi yang transparan, organisasi yang akuntabel serta tata kelola perusahaan yang semakin bagus semakin memaksa perusahaan untuk memberikan informasi mengenai aktifitas sosialnya (Hidayah \& Pamungkas, 2012). Masyarakat perlu mengetahui berbagai kegiatan sosial perusahaan sebagai realisasi dari program corporate social responsibility yang dicanangkan. Pengungkapan informasi tersebut setidaknya memberikan jaminan kepada 
masyarakat luas akan keamanan aktifitas yang dijalankannya. Para buruh dan karyawan pun serta masyarakat setempat akan merasa diperhatikan dan dijamin kesejahteraan hidupnya.

Seiring perkembangan waktu, perusahaan dituntut untuk bertanggungjawab secara sosial. Perusahaan harus memperhatikan kondisi masyarakat yang berada di sekitar perusahaan agar masyarakat juga dapat merasakan manfaat dari perusahaan. Perhatian tersebut dapat berupa pendidikan dan kesehatan, dimana saat biaya pendidikan semakin mahal dan sulit terjangkau, maka disitulah peran perhatian atau bantuan perusahaan untuk meringankan beban pendidikan dengan memberikan tenaga pendidik atau memberikan tunjangan pendidikan secara berkala.

Selain itu, memberikan bantuan kesehatan yang bisa mengarahkan kepada masyarakat sekitar untuk bisa hidup dengan pola sehat. Dari dukungan sosial ini, nantinya dapat berimbas pula terhadap citra perusaan karena bagaimanapun juga kegiatan sosial yang mendukung kesejahteraan masyarakat sangat menunjang reputasi di mata masyarakat dengan baik. Kotler dan Lee (2005) menyatakan bahwa corporate social responsibility memiliki kemampuan untuk meningkatkan citra perusahaan karena jika perusahaan menjalankan tata kelola bisnisnya dengan baik dan mengikuti peraturan yang telah ditetapkan oleh pemerintah maka pemerintah dan masyarakat akan memberikan keleluasaan bagi perusahaan tersebut untuk beroperasi di wilayah mereka. Publik akan menganggap bahwa perusahaan tersebut cukup peduli dengan lingkungan sekitar sehingga akan muncul citra yang positf terhadap perusahaan (Mulyana \& Sari, 2013).

Salah satu keuntungan dari corporate social responsibility adalah meningkatnya citra positif perusahaan. Corporate social responsibility merupakan salah satu kegiatan positif yang dilakukan oleh perusahaan, dan tentu saja bila perusahaan melakukan kegiatan yang positif serta bermanfaat untuk banyak pihak, perusahaan tersebut akan mendapatkan feedback yang positif pula. Oleh sebab itu, perusahaan melakukan kegiatan corporate social responsibility sebagai sarana untuk membangun citra positif baik di media masa maupun di mata masyarakat luas (Fitriani, 2012).

\section{Citra Perusahaan}

Citra perusahaan merupakan total persepsi terhadap suatu objek yang dibentuk dengan memproses informasi dari berbagai sumber setiap waktu. Sedangkan persepsi adalah proses yang dilalui orang dalam memilih, mengorganisasikan, dan menginterpretasikan informasi guna membentuk gambaran yang berarti mengenai dunia. Citra konsumen yang positif terhadap suatu merek lebih memungkinkan konsumen untuk melakukan pembelian. Merek yang baik menjadi dasar untuk citra perusahaan yang positif.

Kotler (2002) menyatakan bahwa citra adalah seperangkat keyakinan, ide dan kesan yang dimiliki oleh seseorang terhadap suatu objek. Selain itu, Nguyen dan Leblanc (2001) berpendapat bahwa citra perusahaan berhubungan dengan fisik dan atribut yang berhubungan dengan perusahaan, seperti nama, bangunan, produk atau jasa untuk mempengaruhi kualitas yang dikomunikasikan oleh setiap orang agar tertarik dengan perusahaan. Citra menggambarkan keseluruhan kesan yang dibuat publik tentang perusahaan dan produknya. Lebih lanjut Kotler (1997) menyatakan bahwa perusahaan yang mempunyai kredibilitas tinggi yang mampu membentuk citra yang positif. 
Kotler dan Keller (2012) mengungkapkan bahwa informasi yang lengkap mengenai citra perusahaan meliputi empat elemen sebagai berikut (1) Kepribadian, keseluruhan karakteristrik yang dipahami publik sasaran, seperti perusahaan yang dapat dipercaya, perusahaan yang mempunyai tanggung jawab sosial; (2) Reputasi, hak yang telah dilakukan perusahaan dan diyakini publik sasaran berdasarkan pengalaman sendiri maupun pihak lain, seperti kinerja keamanan transaksi sebuah bank; (3) Nilai, nilainilai yang dimiliki suatu perusahaan dengan kata lain budaya perusahaan seperti sikap manajemen yang peduli terhadap pelanggan, karyawan yang cepat tanggap terhadap permintaan maupun keluhan pelanggan; dan (4) Identitas Perusahaan, komponenkomponen yang mempermudah pengenalan publik sasaran terhadap perusahaan, seperti logo, warna, dan slogan. Perkembangan perusahaan tergantung pada baiknya citra perusahaan tersebut. Begitupun sebaliknya, jika citra perusahaan buruk, maka sangat merugikan perkembangan perusahaan. Dalam konsep bisnis saat ini citra menjadi perhatian serius demi kelangsungan hidup perusahaan, untuk itu perlu dibangun indikator dalam pengembangan citra tersebut.

\section{METODE PENELITIAN}

Penelitian ini bersifat kuantitatif dan menggunakan jenis penelitian lapangan. Penelitian kuantitatif ini memandang bahwa realitas atau fenomena dapat diklasifikasikan, relatif tetap, konkrit, teramati, terukur dan hubungan gejala bersifat sebab akibat. Penelitian ini berfokus pada hal-hal yang berkaitan dengan kualitas pelayanan, corporate social responsibility dan citra perusahaan dengan studi kasus pada PT BNI Syariah Pusat, Jakarta.

Analisis yang digunakan oleh peneliti untuk mengetahui pengaruh masing-masing variabel menggunakan teknik analisis regresi linier berganda. Teknik analisis ini dipilih peneliti karena selain untuk mengetahui pengaruh kualitas pelayanan (X1) dan corporate social responsibility $(\mathrm{X} 2)$ terhadap citra perusahaan $(\mathrm{Y})$, juga untuk mengetahui seberapa besar pengaruh kualitas pelayanan dan corporate social responsibility terhadap citra perusahaan. Variabel bebas dalam penelitian ini adalah kualitas pelayanan (X1) dan corporate social responsibility (X2), sedangkan yang menjadi variabel terikatnya, yaitu citra perusahaan (Y) Bank BNI Syariah Pusat Jakarta. Rumus persamaan regresi yang digunakan adalah sebagai berikut:

$\mathrm{Y}=\mathrm{a}+\beta 1 \mathrm{X} 1+\beta 2 \mathrm{X} 2+\mathrm{e}$

Dimana :

$\mathrm{Y}=$ Citra Perusahaan

A $\quad=$ Konstanta

$\mathrm{B} 1, \beta 2=$ Koefisien regresi

$\mathrm{X} 1=$ Kualitas layanan

$\mathrm{X} 2=$ Corporate social responsibility

$\mathrm{e} \quad=$ Standar error 


\section{HASIL DAN PEMBAHASAN}

Pengujian pertama kali dilakukan dengan menguji kualitas data yang meliputi uji validitas data dan uji reliabilitas data. Uji validitas digunakan untuk mengukur sah atau valid tidaknya suatu kuesioner (Ghozali, 2011). Uji validitas dilakukan dengan membandingkan nilai rhitung dengan rtabel. Dari hasil perhitungan didapat bahwa nilai rhitung $>$ rtabel sehingga butir pertanyaan dinyatakan valid. Sedangkan uji reliabilitas data dilakukan dengan menguji cronbach's alpha. Dari hasil perhitungan cronbach's alpha $>$ rtabel $(0,7)$ sehingga butir pertanyaan dinyatakan reliabel (konsisten).

Tabel 3. Hasil Uji Reliabilitas Data

\begin{tabular}{cccccc}
\hline \multicolumn{2}{l}{ Kualitas Pelayanan $\left(\mathrm{X}_{1}\right)$} & \multicolumn{2}{c}{$\begin{array}{c}\text { Corporate Social Responsi- } \\
\text { bility }\left(\mathrm{X}_{2}\right)\end{array}$} & \multicolumn{2}{c}{ Citra $(\mathrm{Y})$} \\
\hline $\begin{array}{c}\text { Cronbach's } \\
\text { Alpha }\end{array}$ & Items & Cronbach's & Nof Items & Cronbach's & Nof \\
Alpha & Items \\
\hline 0,860 & 10 & 0,822 & 10 & 0,828 & 10 \\
\hline
\end{tabular}

Sumber: Hasil Pengolahan Data Primer

Selanjutnya, sebelum menggunakan analisis regresi berganda, dilakukan uji prasyarat, yaitu uji normalitas, uji multikolinearitas dan uji heteroskedastisitas. Uji normalitas diperoleh dari pengujian uji kolmogorov-smirnov yang menunjukkan bahwa tingkat signifikansi residual sebesar 0,190 yang lebih besar dari 0,05 sehingga dapat disimpulkan bahwa data terdistribusi normal. Kemudian dari uji multikolinearitas menggunakan uji Variance Inflation Factor (VIF) dengan masing-masing variabel independen memiliki $1,002<10$ dan nilai Toleransi 0,998 $>0,1$ sehingga pada penelitian ini bebas dari multikolinearitas. Terakhir adalah uji heteroskedastisitas diperoleh hasil Sig $>5 \%$ sehingga tidak terjadi gejala heteroskedastisitas.

Tabel 4. Hasil Uji Validitas Data

\begin{tabular}{cccccccccc}
\hline Pert. & $\mathbf{r}_{\text {hitung }}$ & $\mathbf{r}_{\text {tabel }}$ & Pert. & $\mathbf{r}_{\text {hitung }}$ & $\mathbf{r}_{\text {tabel }}$ & Pert. & $\mathbf{r}_{\text {hitung }}$ & $\mathbf{r}_{\text {tabel }}$ & Ket \\
\hline $\mathrm{X}_{1.1}$ & 0,485 & 0,1966 & $\mathrm{X}_{2.1}$ & 0,721 & 0,1966 & $\mathrm{Y}_{1}$ & 0,449 & 0,1966 & Valid \\
$\mathrm{X}_{1.2}$ & 0,654 & 0,1966 & $\mathrm{X}_{2.2}$ & 0,673 & 0,1966 & $\mathrm{Y}_{2}$ & 0,656 & 0,1966 & Valid \\
$\mathrm{X}_{1.3}$ & 0,633 & 0,1966 & $\mathrm{X}_{2.3}$ & 0,744 & 0,1966 & $\mathrm{Y}_{3}$ & 0,648 & 0,1966 & Valid \\
$\mathrm{X}_{1.4}$ & 0,699 & 0,1966 & $\mathrm{X}_{2.4}$ & 0,753 & 0,1966 & $\mathrm{Y}_{4}$ & 0,467 & 0,1966 & Valid \\
$\mathrm{X}_{1.5}$ & 0,773 & 0,1966 & $\mathrm{X}_{2.5}$ & 0,582 & 0,1966 & $\mathrm{Y}_{5}$ & 0,640 & 0,1966 & Valid \\
$\mathrm{X}_{1.6}$ & 0,716 & 0,1966 & $\mathrm{X}_{2.6}$ & 0,818 & 0,1966 & $\mathrm{Y}_{6}$ & 0,572 & 0,1966 & Valid \\
$\mathrm{X}_{1.7}$ & 0,610 & 0,1966 & $\mathrm{X}_{2.7}$ & 0,826 & 0,1966 & $\mathrm{Y}_{7}$ & 0,478 & 0,1966 & Valid \\
$\mathrm{X}_{1.8}$ & 0,544 & 0,1966 & $\mathrm{X}_{2.8}$ & 0,518 & 0,1966 & $\mathrm{Y}_{8}$ & 0,659 & 0,1966 & Valid \\
$\mathrm{X}_{1.9}$ & 0,631 & 0,1966 & $\mathrm{X}_{2.9}$ & 0,735 & 0,1966 & $\mathrm{Y}_{9}$ & 0,569 & 0,1966 & Valid \\
$\mathrm{X}_{1.10}$ & 0,677 & 0,1966 & $\mathrm{X}_{2.10}$ & 0,761 & 0,1966 & $\mathrm{Y}_{10}$ & 0,601 & 0,1966 & Valid \\
\hline
\end{tabular}


Penelitian ini menggunakan analisis regresi linear berganda untuk pembuktian hipotesis penelitian. Analisis yang dilakukan berdasarkan pada data yang diperoleh dari kuesioner. Adapun persamaan regresi linear berganda dari hasil pengolahan adalah sebagai berikut:

$\mathrm{Y}=10,218+0,489 \mathrm{X} 1-0,092 \mathrm{X} 2+\mathrm{e}$

Dari hasil persamaan regresi linear berganda diatas dapat dijelaskan bahwa (1) apabila variabel lain bernilai konstan maka nilai $\mathrm{Y}$ akan berubah dengan sendirinya sebesar nilai konstanta, yaitu 10,218; (2) apabila variabel lain bernilai konstan maka Nilai Y akan berubah sebesar 0,489 setiap satu satuan X1; dan (3) apabila variabel lain bernilai konstan maka nilai Y akan berubah sebesar - 0,092 setiap satu satuan X2.

Uji R square

Dari hasil pengujian koefisien determinasi yang telah dilakukan terhadap data yang ada, maka diperoleh data sebagai berikut:

Tabel 5. Hasil Uji R Square

Model Summary

\begin{tabular}{|c|c|c|c|c|c|}
\hline Model & $\mathrm{R}$ & $R$ Square & $\begin{array}{c}\text { Adjusted } R \\
\text { Square }\end{array}$ & $\begin{array}{l}\text { Std. Error of } \\
\text { the Estimate }\end{array}$ & Durbin-Watson \\
\hline 1 & $.856^{\mathrm{a}}$ & .733 & .727 & 1.556 & 1.815 \\
\hline
\end{tabular}

Sumber : Hasil Pengolahan Data Primer

Dalam Tabel 5 diatas, menunjukkan bahwa nilai R Square adalah 0,733 atau $73,3 \%$. Hal ini berarti bahwa variabel independen, yaitu kualitas layanan dan corporate social responsibility mampu menjelaskan variabel dependen, yaitu citra perusahaan BNI Syariah sebesar $73,3 \%$. Sedangkan sisanya sebesar $26,7 \%$ ditentukan atau dijelaskan oleh variabel lain yang tidak termasuk dalam penelitian ini. Karena R Square berkisar pada angka 0 sampai 1, dengan catatan semakin besar angka $\mathrm{R}$ Square maka semakin kuat variabelnya. Seperti diketahui $73,3 \%$ keputusan nasabah terhadap citra perusahaan BNI Syariah dapat dijelaskan oleh variabel kualitas layanan dan corporate social responsibility, artinya $26,7 \%$ dipengaruhi oleh variabel lain, seperti fasilitas, bagi hasil ataupun variabel lain yang tidak dimasukkan dalam penelitian ini.

\section{Uji F}

Pada Tabel 6, dalam model ANOVA dapat diperoleh Fhitung sebesar 321,655 dengan probabilitas 0.000 karena probabilitas jauh lebih kecil dari 0,05. Maka dapat disimpulkan bahwa variabel independen, yaitu kualitas layanan dan corporate social responsibility secara bersama-sama memberi pengaruh yang signifikan terhadap citra perusahaan BNI Syariah. Sehingga model regresi yang didapatkan layak digunakan untuk memprediksi. Maka dapat disimpulkan bahwa H0 ditolak dan Ha diterima. 
Tabel 6. Hasil Uji F

ANOVA $^{\mathrm{a}}$

\begin{tabular}{llrrrrr}
\hline & Model & \multicolumn{1}{c}{$\begin{array}{c}\text { Sum of } \\
\text { Squares }\end{array}$} & \multicolumn{1}{c}{ df } & \multicolumn{1}{c}{$\begin{array}{c}\text { Mean } \\
\text { Square }\end{array}$} & F & Sig. \\
\hline 1 & Regression & 643.310 & 2 & 321.655 & 132.836 & $.000^{\mathrm{b}}$ \\
& Residual & 234.880 & 97 & 2.421 & & \\
$\quad$ Total & 878.190 & 99 & & & \\
\hline
\end{tabular}

a. Dependent Variable: $\mathrm{Y}$

b. Predictors: (Constant), $\mathrm{X}_{2}, \mathrm{X}_{1}$

Sumber : Hasil Pengolahan Data Primer

\section{Uji T}

Uji T parsial dalam analisis regresi linear berganda bertujuan untuk mengetahui apakah variabel bebas (X) secara parsial (sendiri-sendiri/masing-masing variabel) memiliki pengaruh secara signifikan terhadap variabel terikat (Y). Dasar dari uji $\mathrm{T}$ menggunakan penggunaaan nilai thitung dan ttabel dengan aturan jika nilai $\mid$ thitung $\mid>$ ttabel maka variabel bebas $(\mathrm{X})$ memiliki pengaruh secara signifikan terhadap variabel terikat $(\mathrm{Y})$ dan jika nilai $\mid$ thitung $\mid<$ ttabel maka variabel bebas $(\mathrm{X})$ tidak berpengaruh terhadap variael terikat $(\mathrm{Y})$. Berdasarkan hasil pengolahan, selengkapnya dijelaskan pada Tabel 7 berikut ini.

Tabel 7. Hasil Uji T

\begin{tabular}{|c|c|c|c|c|c|c|}
\hline \multirow{2}{*}{\multicolumn{2}{|c|}{ Model B }} & \multicolumn{2}{|c|}{$\begin{array}{c}\text { Unstandardized } \\
\text { Coefficients }\end{array}$} & \multirow[t]{2}{*}{$\begin{array}{c}\text { Standardized } \\
\text { Coefficients }\end{array}$} & \multirow[t]{2}{*}{$\mathrm{T}$} & \multirow[t]{2}{*}{ Sig. } \\
\hline & & Std. Error & Beta & & & \\
\hline \multirow{3}{*}{1} & (Constant) & 10.218 & 3.392 & & 3.012 & .003 \\
\hline & $X_{1}$ & .489 & .030 & .842 & 16.030 & .000 \\
\hline & $\mathrm{X}_{2}$ & -.092 & .026 & -.183 & -3.479 & .001 \\
\hline
\end{tabular}

a. Dependent Variable: Y

Sumber : Hasil Pengolahan Data Primer

Berdasarkan Tabel 7 diatas, untuk mengetahui besarnya pengaruh masing-masing variabel independen secara parsial terhadap variabel dependen adalah sebagai berikut:

1) Pengaruh Antara Kualitas Layanan Terhadap Citra Perusahaan BNI Syariah

Berdasarkan |thitung| untuk variabel kualitas layanan adalah 16,030. Sedangkan ttabel dihitung pada tabel ttest, dengan $\alpha=0,05$ dan menggunakan hipotesis dua arah, ketika mencari ttabel, nilai $\alpha$ dibagi dua menjadi 0,025 dengan $\mathrm{df}=96$ maka didapat ttabel adalah 1,988. Sehingga nilai $\mid$ thitung $\mid>$ ttabel $(16,030>1,988)$, maka H0 ditolak dan Ha diterima. Variabel kualitas layanan memiliki nilai signifikansi $0,000<0,05$ artinya signifikan dan positif, sehingga dapat disimpulkan bahwa variabel kualitas layanan secara parsial berpengaruh positif dan signifikan terhadap citra perusahaan BNI Syariah.

2) Pengaruh Antara Corporate Social Responsibility Terhadap Citra Perusahaan Bank BNI Syariah 
Berdasarkan |thitung| untuk variabel corporate social responsibility adalah 3,479. Sedangkan ttabel dihitung pada tabel ttest, dengan $\alpha=0.05$ dan menggunakan hipotesis dua arah, ketika mencari ttabel, nilai $\alpha$ dibagi dua menjadi 0,025 dengan $\mathrm{df}=96$ maka didapat ttabel adalah 1,988. Sehingga nilai $\mid$ thitung $\mid>$ ttabel $(3,479>1,988)$, maka H0 ditolak dan Ha diterima. Variabel corporate social responsibility memiliki nilai signifikansi $0,001<0,05$ artinya signifikan dan positif, sehingga dapat disimpulkan bahwa variabel corporate social responsibility secara parsial berpengaruh positif dan signifikan terhadap citra perusahaan BNI Syariah.

Pengaruh kualitas layanan terhadap citra perusahaan BNI Syariah dapat dilihat berdasarkan hasil uji regresi linear berganda, variabel kualitas layanan mempunyai nilai signifikan $0,000<0,05$ yang berarti $\mathrm{H} 0$ ditolak dan Ha diterima, sehingga dapat disimpulkan bahwa variabel kualitas layanan secara parsial berpengaruh signifikan terhadap citra perusahaan BNI Syariah Pusat Jakarta. Hasil ini sesuai dengan penelitian yang dilakukan oleh Firdaus dan Idris (2014) dengan menggunakan regresi berganda dan uji hipotesis dengan menggunakan uji $\mathrm{F}$ dan uji $\mathrm{t}$ mendapatkan hasil bahwa corporate social responsibility, kualitas pelayanan dan promosi memiliki pengaruh signifikan terhadap kualitas pelayanan telkomsel di kota Padang.

Begitu pula dengan penelitian yang dilakukan oleh Chang dan Yeh (2017) dengan melakukan interaksi antara variabel kualitas layanan, citra perusahaan dan kepuasan pelanggan dalam mempengaruhi loyalitas pelanggan. Pendekatan yang digunakan menggunakan pemodelan persamaan structural dan memperoleh hasil bahwa kualitas pelayanan memiliki peranan penting dalam meningkatkan citra perusahaan Bus di Taiwan. Yuen, Thai, Wong, dan Wang (2018) juga melakukan penelitian yang sama, diawali dengan melakukan wawancara dan survei yang dilakukan pada 156 perusahaan pelayaran yang beroperasi di Singapura. Data yang terkumpul dianalisis menggunakan pemodelan persamaan struktural. Dari penelitian tersebut, didapatkan hasil bahwa kualitas pelayanan dan corporate social responsibility merupakan variabel yang saling melengkapi dalam mendorong kepuasan pelanggan sehingga meningkatkan citra perusahaan pelayaran di Singapura.

Dari hasil analisis ini menunjukan bahwa variabel kualitas layanan memiliki pengaruh terhadap citra perusahaan BNI Syariah. Semakin tinggi kualitas layanan yang diberikan oleh bank, maka akan meningkatkan citra perusahaan BNI Syariah. Jika kualitas layanan rendah, maka akan rendah citra perusahaan BNI Syariah. Sehingga diharapkan bank syariah dapat meningkatkan kualitas layanan pada setiap aktivitas bisnisnya, terlebih lagi akan dapat meningkatkan citra perusahaan BNI Syariah dan memiliki tingkat kompetisi yang lebih baik dibandingkan bank konvensional.

Pengaruh corporate social responsibility terhadap citra perusahaan BNI Syariah dapat dilihat berdasarkan hasil uji regresi linear berganda bahwa variabel corporate social responsibility mempunyai nilai signifikan $0,001<0,05$. Hal ini berarti menolak H0 dan menerima Ha sehingga dapat disimpulkan bahwa variabel corporate social responsibility secara parsial berpengaruh signifikan terhadap citra perusahaan BNI Syariah. Hasil Penelitian ini mendukung hasil penelitian yang dilakukan oleh Rini dan Sulistiyawati (2012) dengan menggunakan sampel sebanyak 120 responden dengan metode purposive sampling. Teknik analisis data yang digunakan adalah teknik analisis regresi linier berganda, hasil yang diperoleh menunjukkan bahwa faktor-faktor brand 
trust, customer satisfaction dan corporate social responsibility adalah faktor-faktor yang memiliki pengaruh pada brand loyalty konseumen Aqua, namun diantara faktor-faktor yang diujikan, corporate social responsibility merupakan faktor yang paling berpengaruh dari pada faktor-faktor lainnya yang diujikan.

Penelitian yang terkait dengan corporate social responsibility juga dilakukan oleh Bhardwaj, Chatterjee, Demir, dan Turut (2018) yang menjelaskan bahwa perusahaan di berbagai pasar, seperti perawatan kesehatan, layanan keuangan, perangkat lunak, barang-barang konsumsi dan lainnya menghabiskan sejumlah besar uang untuk kegiatan corporate social responsibility. Hasil tersebut juga menunjukan bahwa konsumen mempertimbangkan kegiatan corporate social responsibility perusahaan ketika membuat keputusan, mencatat dan melakukannya baik meningkatkan niat pembelian mereka atau membuat mereka bersedia membayar harga lebih tinggi untuk produk dan layanan perusahaan.

Mallin, Farrag, dan Yong (2014) meneliti hubungan antara corporate social responsibility dan kinerja keuangan di bank-bank Islam dengan menggunakan indeks corporate social responsibility secara komprehensif yang mencakup sepuluh dimensi dengan menggunakan sampel 90 bank Islam di 13 negara meliputi Bahrain, Bangladesh, Indonesia, Jordan, Kuwait, Malaysia, Pakistan, Qatar, Saudi Arabia, Sudan, Syria, United Arab Emirates (UAE) dan United Kingdom (UK). Indeks corporate social responsibility menunjukkan bahwa bank-bank Islam terlibat dalam berbagai kegiatan sosial. Terlebih lagi bank Islam menunjukkan komitmen yang lebih besar terhadap visi dan misi perusahaan, dimensi produk dan layanan keuangan. Bank-bank Islam juga menunjukkan kesadaran yang cukup besar untuk memperhatikan kegiatan corporate social responsibility demi meningkatkan citra perusahaan mereka. Jadi, corporate social responsibility sangat penting terhadap sesuatu hal dalam mengambil keputusan. Baik buruknya kualitas corporate social responsibility perusahaan akan mempengaruhi sesorang dalam memahami citra perusahaan pada kehidupan sehari-hari. Masyarakat yang mengetahui kegiatan corporate social responsibility berjalan baik dalam mengimplementasikannya kepada masyarakat maka akan semakin tinggi citra perusahaan BNI Syariah.

\section{KESIMPULAN}

Dari penelitian ini dapat diambil kesimpulan bahwa semakin tinggi kualitas layanan dan semakin baik kegiatan corporate social responsibility, maka akan meningkatkan citra perusahaan BNI Syariah. Hasil pengujian secara simultan menunjukkan bahwa kualitas layanan dan corporate social responsibility memiliki nilai R Square sebesar $73,3 \%$. Hal ini berarti bahwa kualitas layanan dan corporate social responsibility mampu menjelaskan citra perusahaan BNI Syariah sebesar 73,3\%. Sedangkan sisanya sebesar $26,7 \%$ ditentukan atau dijelaskan oleh variabel lain yang tidak termasuk dalam penelitian ini.

Sedangkan dari uji F diperoleh Fhitung sebesar 321,655 dengan probabilitas 0.000 sehingga kualitas layanan dan corporate social responsibility secara bersamasama memberi pengaruh yang signifikan terhadap citra perusahaan BNI Syariah. Terakhir, hasil dari uji secara parsial menunjukkan bahwa variabel kualitas layanan memiliki pengaruh signifikan terhadap citra perusahaan dan variabel corporate social 
responsibility memiliki pengaruh signifikan terhadap citra perusahaan. Sehingga dapat disimpulkan bahwa perusahaan BNI Syariah perlu memperhatikan variabel kualitas layanan dan corporate social responsibility untuk meningkatkan citra perusahaan di mata masyarakat.

\section{DAFTAR PUSTAKA}

Adona, F. (2006). Citra dan Kekerasan Dalam Iklan Perusahaan di Televisi. Padang: Andalas University Press.

Bhardwaj, P., Chatterjee P., Demir, K. D., \& Turut, O. (2018). When and How Is Corporate Social Responsibility Profitable? Journal of Business Research, 84(3): 206-219.

Budimanta, A., Prasetijo, A., \& Rudito, B. (2004). Corporate Social Responsibility, Jawaban bagi Model Pembangunan Indonesia Masa Kini. Jakarta: ICSD.

Chang, Y. H., \& Yeh, C. H. (2017). Corporate Social Responsibility and Customer Loyalty in Intercity Bus Services. Journal Transport Policy, 59: 38-45.

Dick, A. S., \& Basu, K. (1994). Customer Loyalty: Toward an Integrated Conceptual Framework. Journal of the Academy of Marketing Science, 22, 99-113.

Doney, P. M., \& Cannon, J. P. 1997. An Examinitation of The Nature of Trust in Buyer-Seller Relationship. Journal of Marketing, 61(1): 35-51.

Elkington, J. (1998). Cannibals With Forks: The Triple Bottom Line in $21^{\text {st }}$ Century Business, Gabriola Island. BC: New Society Publishers.

Firdaus, T. R. F., \& Idris. (2014). Pengaruh Corporate Social Responsibility, Kualitas Pelayanan dan Promosi terhadap Brand Image Telkomsel di Kota Padang. Jurnal Riset Manajemen Bisnis dan Publik, 2(2): 1-12.

Fitriani, P. (2012). Pengaruh Kegiatan Corporate Social Responsibility Terhadap Citra Perusahaan (studi pada program Beasiswa Unggulan CIMB Niaga 2011) [Skripsi]. Depok: Universitas Indonesia.

Ghozali, I. (2011). Aplikasi Analisis Multivariate Dengan Program SPSS. Semarang: Badan Penerbit Universitas Diponegoro.

Hidayah, E., \& Pamungkas, W. (2012). Analisis Pengaruh Karakteristik Perusahaan Terhadap Pengungkapan Tanggungjawab Sosial Perusahaan dalam Laporan Tahunan Perusahaan Manufaktur yang Terdaftar di BEI Periode 2009-2010. Jurnal Aplikasi Bisnis, 13(9): 1487-1504

Jasfar, F. (2009). Manajemen Jasa Pendekatan Terbaru. Bogor: Ghalia Indonesia.

Karsono. (2008). Pengaruh Komitmen Organisasi Terhadap Kinerja Dengan Motivasi dan Kepuasan Kerja Sebagai Variabel Pemedisi. Jurnal Akuntansi dan Bisnis, 3(1): 34-67.

Kotler, P. (1997). Marketing Management Analysis, Planning, Implementation and Control $9^{\text {th }}$ ed. New Jersey: Prentice Hall.

Kotler, P. (2002). Manajemen Pemasaran. Jakarta: Prebalindo.

Kotler, P., \& Lee, N. (2005). Corporate Social Responsibility: Doing the Most Good for Your Company and Your Cause. New Jersey: John Wiley \& Sons Inc.

Kotler, P., \& Keller, K. L. (2012). Marketing Management. New Jersey: Pearson Prentice Hall Inc.

Mallin, C., Farag, H., \& Yong, K. O. (2014). Corporate Social Responsibility and Financial Performance in Islamic Banks. Journal of Economic Behavior \& Organization, 103(6): 221-238.

Mardikanto, T. (2014). Tanggungjawab Sosial Korporasi. Bandung: Alfabeta.

Monitor, B. H. T. (2001). When Consumer Trust Goes, So Do Customers; The Booth/Harris Trust Monitor Finds Service is Key to Maintaining Consumer Loyalty. Retrieved from http:// www.thefreelibrary.com/ 
Mulyana., \& Sari, D. A. W. (2013). Implementasi Corporate Social Responsibility Sebagai Bentuk Citra Perusahaan dan Loyalitas. Jurnal Ekobis, 14(2): 90-104.

Nguyen, N., \& LeBlanc, G. (2001). Image and Reputation of Higher Education Institutions in Students' Retention Decisions. International Journal of Educational Management, 15(6):303-311.

Prastowo, J., \& Huda, M. (2011). Corporate Social Responsibility, Kunci Meraih Kemuliaan Bisnis. Yogyakarta: Samudera Biru.

Rini, A. S., \& Sulistyawati, E. (2012). Pengaruh Brand Trust, Customer Satisfaction dan Corporate Responsibility Terhadap Brand Loyalty. Jurnal Manajemen, Strategi Bisnis dan Kewirausahaan, 510-529.

Tjiptono, F. (2010). Strategi Pemasaran Ed-2. Yogyakarta: Andi.

Wibisono, Y. (2007). Membedah Konsep Aplikasi Corporate Social Responsibility. Jakarta: Fashco Publishing.

Yuen, K. F., Thai, V. V., Wong, Y. D., \& Wang, X. (2018). Interaction Impacts of Corporate Social Responsibility and Service Quality on Shipping Firms' Performance. Journal Transportation Research Part A, 113(4): 397-409.

Zeithaml, V, A., Parasuraman, A., \& Berry, L. L. (1985). Problems and Strategies in Services Marketing. Journal of Marketing, 49(2): 33-46. 